\title{
Opportunities for improving the safety of dairy parlor workers
}

\author{
J. P. Edwards ${ }^{1 *}$ (1) and B. Kuhn-Sherlock ${ }^{2}$ (우 \\ ${ }^{1}$ DairyNZ Ltd., PO Box 85066, Lincoln University, Lincoln 7647, New Zealand \\ ${ }^{2}$ DairyNZ Ltd., Private Bag 3221, Hamilton 3240, New Zealand
}

\section{ABSTRACT}

One aspect of a successful dairy business is attracting and retaining skilled staff. The ability to do this is influenced by workplace attractiveness, one aspect of which is worker comfort and safety. Working with heavy machinery and animals makes dairy farming a dangerous occupation relative to many other sectors. Milking is the most time-consuming task on pasturebased dairy farms, and the parlor is the logical site of a number of injuries, although little is known about their causes or their relationship to parlor design and management. To investigate worker safety further, we conducted an on-farm survey on New Zealand dairy farms between December 2018 and March 2019. The survey had 3 objectives: to identify common causes of injuries relating to milking; to describe variations in milking parlor design and management practices on dairy farms; and to identify management and parlor factors that contribute to milking injuries. Analysis of accident compensation data from the state-run accident insurer for a 5-yr period from July 2013 to June 2018 was a fourth objective. Accident claims identified as related to milking through a key word search averaged $\mathrm{NZ} \$ 252$ (NZ\$1 was equivalent to US $\$ 0.60$ on May 19, 2020) per claim for non-severe injuries and NZ $\$ 9,334$ per claim for severe injuries, for a total of $\mathrm{NZ} \$ 1.95$ million per year. A total of 136 injuries were reported on 99 of the 560 farms surveyed, and accident insurance claims were made for 53 of these injuries. The survey found that $48 \%$ of injuries occurred while workers were attaching clusters: typically soft-tissue and fracture injuries to fingers, hands, wrists, and arms. Injuries to these body parts represented the greatest cost (51\% of the annual insurance cost) and identified safe cluster attachment as an area of focus for reducing milking injuries. Potential low-cost solutions include improved cluster design and a hand-arm guard. We identified a clear seasonal trend that coincided with busy periods in

Received May 25, 2020.

Accepted September 3, 2020.

*Corresponding author: Paul.Edwards@dairynz.co.nz a seasonal block calving system, suggesting that options to reduce fatigue in spring may be beneficial; however, the number of hours worked or number of consecutive days worked were not associated with the number of milking injuries. Those aged 20-29 yr had more injuries relative to their proportion of the workforce, indicating that more training may be beneficial (e.g., setting ergonomic milking routines). Female workers were at greater risk of injury than males; this finding may have been related to the height of the animal relative to the height of the milker.

Key words: milking, injury, health and safety, cluster attachment

\section{INTRODUCTION}

Increasing the attractiveness of dairy farming in relation to other sectors is a current challenge for many major dairy nations (DairyNZ, 2018; Teagasc, 2018), and maintaining worker safety is an important aspect of these efforts. Agriculture as a sector is disproportionately represented in health and safety statistics, and globally the dairy industry is not insulated from these figures (Douphrate et al., 2013). In their review of ergonomics in modern dairy practice, Douphrate et al. (2013) noted the challenges associated with comparing worker injury and fatality data, with a need to focus on determining causes and implementing solutions to reduce injuries.

Harvesting milk is the most fundamental of tasks on a dairy farm, and it requires significant labor resources. In New Zealand, estimates of the time per farm worker spent milking range from $16 \mathrm{~h} /$ wk for rotary parlors and $23 \mathrm{~h} /$ wk for herringbone parlors (Edwards et al., 2020). In Ireland, it is estimated that 30 to $34 \%$ of annual labor hours relate to milking (Deming et al., 2018), and participants in a study of large-herd dairy parlor workers in the United States worked an average of 9 h/d, $6 \mathrm{~d} / \mathrm{wk}$, for $50 \mathrm{wk} / \mathrm{yr}$ (Douphrate et al., 2016). Given the considerable proportion of time spent in the parlor, it is logical that it would be the location of a large number of injuries in the dairy industry, particularly because it involves working with both animals and 
machinery. This concept is supported by the results of an analysis of Colorado accident compensation data, which found that over a 10 -yr period $31.1 \%$ of injuries on dairy farms involved animals, $47.9 \%$ of injuries involved milking, and $19.2 \%$ involved getting the cows into the parlor (Douphrate et al., 2009). The authors noted that other common causes of injury not included in those numbers can also occur in the parlor, such as falls, slips, or strains. Similarly, Hwang et al. (2001) reported that milking was a risk factor for severe injury in a cohort of New York State farmers. Therefore, the milking parlor is a focal point for identifying common causes of injuries on dairy farms.

Considerable differences exist between dairy systems in which cows are housed predominantly in barns (common in the Europe and North America), and pasturebased grazing dairy systems common in countries such as New Zealand and Ireland. In the context of milking, these differences include the types of parlor configuration, milking practices (e.g., premilking routines), and cow genetics (e.g., udder height and length of milking time). Even within countries, farms with the same parlor type differ considerably in the construction and milking practices desired by the farm owner (Jakob and Liebers, 2017). Globally, limited data are available on the prevalence and causes of acute injuries that occur specifically during milking such as that provided by Douphrate et al. (2009), and to our knowledge this topic has not been explored in pasture-based dairy systems.

To better understand the extent and causes of injury and guide the design of mitigation initiatives, we conducted a survey on New Zealand dairy farms. The survey had 3 objectives: to identify common causes of injuries relating to milking; to describe variations in milking parlor specifications and labor management on dairy farms; and to identify management and parlor factors that contribute to milking injuries. A fourth objective was to analyze injury compensation data from the state-run Accident Compensation Corporation (ACC; Wellington, New Zealand).

\section{MATERIALS AND METHODS}

\section{Survey Questions}

A survey was designed to capture labor management and milking facility design on farms. Survey questions were developed by a group of 6 experts with a range of backgrounds, including human resource management, leadership, milking efficiency, technology use, dairy design, and ergonomics. The survey was piloted on 18 farms between December 5 and 12, 2018. In response to data from the pilot surveys, clarification was made to surveyors to use millimeters for distances. Before surveys were distributed, the farmer (typically the main decision-maker on farm) was read a prepared statement describing the purpose of the survey, the funder of the work, and who would hold the data, and confirming that individual farm data would remain confidential (any published results would be aggregate numbers). The participant was then asked whether they consented to participate in the survey. The names of injured persons were not recorded, nor were those of participants. Participants were also asked if they would like to receive a summary of the survey results, in which case an email address was recorded.

The survey consisted of 3 sections, details of which are explained below. In the first section, the surveyor established whether an injury had occurred on farm relating to milking in the previous 12 mo. Milking was defined as moving cows from the paddock to the parlor, milking, any associated treatments, and moving cows back to the paddock again. We used this broad definition of milking because in pasture-based systems, the time taken to walk the herd to and from the milking parlor can be substantial (Beggs et al., 2015). Injuries included acute injuries and those of gradual onset, such as hearing loss or repetitive strain, but excluded vehicular injuries. If an injury had occurred, the total number of injuries was recorded as a count, and then a series of questions was asked about the most recent injury event, including the stage of the milking process and the activity being carried out when the event occurred. Activities were categorized as moving cows to and from the dairy; tasks associated with milking (including treating cows for mastitis and identifying cows in heat); milking cows (including loading cows into bails, attaching-detaching clusters, applying teat spray); and post-milking (including plant or yard washing). The type of injury and affected body part were also recorded, as well as information about the person involved: role, age, years of experience in the dairy industry, sex, height, the month of the injury, and how many days they had been working since their last rostered day off. If no milking injuries had occurred in the previous $12 \mathrm{mo}$, then the surveyor moved directly to the next section.

In the second section, all respondents were asked questions related to the farm and how it was managed, irrespective of whether an injury had occurred or not. It included questions about the number of staff; the normal work roster in spring; the usual hours of work per week; whether they trained staff in stockmanship skills; the breed of cow on the farm; whether they familiarized heifers with the parlor before calving; whether they performed foremilk stripping; and what their nor- 
mal milking start and end times were at peak lactation (typically October to November).

The third section was completed by the surveyor for each farm, irrespective of whether an injury had occurred or not. It included questions about the milking parlor and animal-handling facilities; the measured weight of the clusters; whether the pit (herringbone) or platform (rotary) had a "nib" (a raised edge); the height of the kick rail; the depth of the pit or height of the platform; whether the collecting yard gate had electricity; whether animal-handling facilities (e.g., for restraining animals) were available; the use of automation technology; and the approximate age of the parlor. The survey also included also questions specific to the parlor type. In New Zealand, herringbone parlors are typically a $50^{\circ}$ swing-over design (without rapid-exit or stanchion bailing), and rotaries are typically of external design. For herringbone parlors, additional data captured were the distance between clusters; the type of row head gate; the teat spraying method; the location of controls for the head gate, meal feeding, and yard gate; the type of rump rail; the horizontal distance from the pit to the rump rail; and whether the pit had a "toe-in" or "step-up" rail. For rotary parlors, additional data captured were the bail depth and whether leg spreaders were present. The surveyor also recorded the peak herd size and number of clusters.

\section{Survey Process}

The target number of surveys was 600: 350 from the North Island and 250 from the South Island, from a total of 8,156 and 3,216 herds, respectively (DairyNZ, 2019). Proportionally, the South Island was oversampled because it had fewer (but larger) farms. In the 2018/19 dairy season, the industry had a North Island:South Island split of 72:28 in terms of herds and 58:42 in terms of cows (DairyNZ, 2019). Data collection began on December 5, 2018, in the North Island and on January 28, 2019, in the South Island. Surveying ended on March 22, 2019, with a total of 560 responses collected (including pilot surveys): 340 from the North Island and 220 from the South Island.

Except for those from the Southland and West Coast regions, surveys were conducted with farmers who supplied their milk to New Zealand's largest milk processor, which had $\sim 80 \%$ market share (Fonterra Cooperative Group, Auckland, New Zealand) following an annual compliance audit of dairy facilities. Nationally, all dairy farms are audited annually to assess their compliance with food safety legislation. In the North Island, surveys were conducted by QCONZ (Hamilton, New Zealand) and in the South Island they were conducted by AsureQuality (Auckland, New Zealand).
In the Southland region, surveys were conducted by QCONZ, but not during an annual audit. Farmers were randomly selected from a list of Fonterra suppliers; however, in cases of multiple farm ownership, connected farms were also surveyed, some of which supplied their milk to other processors. On the West Coast, surveys were conducted by a local DairyNZ (Hamilton, New Zealand) staff member, not during an annual audit; farmers supplied Westland Milk Products (Hokitika, New Zealand) and were randomly selected from a supplier list. In both regions, these differences were because of AsureQuality staff shortages. To maximize the consistency of data collection across surveyors, a training presentation that contained a description and explanation of each question and measurement was delivered in person. The presentation included photos to ensure that measurements were made in the same location of the parlor.

Survey results were entered into a secure online system (iLeader; QCONZ), and at completion of the survey, data were exported from the system as a comma-separated value file. Surveys typically took $25 \mathrm{~min}$ to complete, of which 15 min were spent talking to the farmer and $10 \mathrm{~min}$ were spent taking measurements of the milking parlor.

\section{National Accident Compensation Data}

An extract of all injuries with the classification unit of dairy cattle farming was provided on October 9, 2019 , by the ACC. The extract contained 41,817 incidents from July 1, 2013, to June 30, 2018, with each row containing a single incident. Fields included the accident date; the compensation amount and number of days off work; the medical fee cost; a description of the accident (free text); the age of the person injured; the type of injury; and the affected body part. A key word filter was used in the accident description field in an attempt to identify injuries related to milking. Key words used were "milking," "cupping," "cluster," "rotary," "herringbone," "tail," "teat," "hose," "hosing," "pit," "cowshed," and "cow shed." This list included colloquial terms such as "cupping" (referring to attaching teat cups) and "cowshed" (referring to the milking parlor). The search resulted in 4,935 records, or $11.8 \%$ of injury incidents over the $5 \mathrm{yr}$. All monetary values are reported in NZ $\$$ (equivalent to US $\$ 0.60$ on May 19, 2020).

\section{Data Processing and Analysis}

All survey data were analyzed using SAS 9.4 (SAS Institute Inc., Cary, NC) with SAS/STAT 15.1. The number of injuries and activities that led to the injury 
Table 1. Numbers of milking injuries reported on New Zealand dairy farms surveyed in 2018/19, including the activity when the injury occurred

\begin{tabular}{|c|c|c|c|c|c|}
\hline Report & Total (n) & Injuries (n) & Injuries $(\%)$ & Lower CI & Upper CI \\
\hline Farms with injuries (all farms) & 560 & 99 & 17.7 & 14.6 & 21.1 \\
\hline Farms with accident claims (all farms) & 560 & 53 & 9.5 & 7.2 & 12.2 \\
\hline Compensation claims (farms with an injury) & 99 & 53 & 53.5 & 43.2 & 63.6 \\
\hline Number of injuries (farms with an injury) & 99 & 136 & 137.4 & 115.3 & 162.5 \\
\hline Number of injuries (all farms) & 560 & 136 & 24.3 & 20.8 & 28.1 \\
\hline \multicolumn{6}{|l|}{$\begin{array}{l}\text { Activity and sub-activity during milking } \\
\text { (farms with an injury })^{1}\end{array}$} \\
\hline Moving cows & 99 & 11 & 11.1 & 5.7 & 19.0 \\
\hline Loading exiting cows & 99 & 15 & 15.2 & 8.7 & 23.8 \\
\hline Activity at milking & 99 & 26 & 26.3 & 17.9 & 36.1 \\
\hline Treating cows & 99 & 11 & 11.1 & 5.7 & 19.0 \\
\hline Heat detection & 99 & 4 & 4.0 & 1.1 & 10.0 \\
\hline Drafting & 99 & 2 & 2.0 & 0.2 & 7.1 \\
\hline Milking cows & 99 & 55 & 55.6 & 45.2 & 65.6 \\
\hline Attaching clusters & 99 & 47 & 47.5 & 37.3 & 57.8 \\
\hline Post-milking & 99 & 12 & 12.1 & 6.4 & 20.2 \\
\hline Washdown & 99 & 6 & 6.1 & 2.3 & 12.7 \\
\hline Mixing chemicals & 99 & 3 & 3.0 & 0.6 & 8.6 \\
\hline Other & 99 & 8 & 8.1 & 3.6 & 15.3 \\
\hline
\end{tabular}

${ }^{1}$ Only most common sub-activity(ies) shown.

were summarized as counts and binomial proportions with $95 \%$ confidence intervals (Proc FREQ). Farm characteristics were summarized by parlor type and overall as count; mean and standard deviation; and minimum, maximum, and quartiles (Proc MEANS). For comparison of farm characteristics between parlor type and farms with and without injuries, the data were subjected to 2-way ANOVA with parlor type, injury, and their interaction included as fixed effects (Proc MIXED). Results are presented as least squares means and standard error of the difference. Accident compensation data and the comparison of injury numbers between this data and survey data were conducted using Minitab 18.1 (Minitab Inc., State College, PA). The number of injuries, the time of year when they occurred, the injured body part and injury type, and costs associated with those injuries were summarized using simple descriptive statistics such as count, percentage, mean, and sum; these were not weighted by year. Comparison of injury numbers by sex and age groups for the different sources (on-farm survey, accident claims database, and workforce) were performed using cross-tabulation and $\chi^{2}$ test of independence.

\section{RESULTS}

\section{Survey Results}

A total of 136 injuries were reported on 99 of the 560 farms surveyed (Table 1). Of the 99 farms with injuries, 23 reported multiple injuries. Injuries were most likely to occur when workers were actively milking cows (par- ticularly attaching clusters to cows; $48 \%$ of injuries), or during an activity being done at milking (e.g., treating mastitis; 11\%). Of the 99 injuries, 49 involved a kick from a cow; 15 (31\%) were from heifers, and $13(87 \%)$ of those heifer-kick injuries happened while attaching clusters. Alternatively, of the kick injuries, $33(67 \%)$ occurred while attaching clusters, and 13 (39\%) of those that occurred while attaching clusters were from heifers.

The most common type of injury while attaching clusters were soft-tissue injuries, bruises, or contusions (51\%), and fractures or breaks $(18 \%)$, which affected the hand-wrist (35\%), arm-elbow (28\%), and fingerthumb (20\%). The most common injury type for armelbow and hand-wrist was a soft-tissue injury, whereas the most common injury type for the finger-thumb was fractures or breaks. For most injuries $(65 \%)$, the worker took no time off work to recover.

Compensation from ACC was claimed for the injury described in the survey on 53 of the 99 farms with an injury. In this group, we found no association between the activity taking place when the injury occurred and whether an ACC claim was made $(P=0.927$; i.e., ACC claims were in proportion to the number of injuries reported for each activity).

In terms of the person injured, the median experience of dairying was $10 \mathrm{yr}$ [interquartile range (IQR) 3 to $20 \mathrm{yr}$ ], and their median height was $1.70 \mathrm{~m}$ (IQR 1.62 to $1.78 \mathrm{~m}$ ). The injury occurred a median of $3 \mathrm{~d}$ after the last rostered day off (IQR 1 to 7 d). Farm assistants were injured most commonly ( $28 \%$ of injuries), followed by farm owners or producers (15\%), assistant managers 
Table 2. Insurance claims and costs (all in NZ dollars) and milking-related claims from an extract of accident compensation claims from July 1,2013 , to June $30,2018^{1}$

\begin{tabular}{|c|c|c|c|c|c|c|c|c|c|c|}
\hline \multirow[b]{2}{*}{ Year } & \multirow[b]{2}{*}{$\begin{array}{l}\text { Claims } \\
\text { (n) }\end{array}$} & \multirow[b]{2}{*}{$\begin{array}{l}\text { Milking- } \\
\text { related } \\
\text { claims (n) }\end{array}$} & \multirow[b]{2}{*}{$\begin{array}{c}\text { Milking } \\
\text { injuries (\%) }\end{array}$} & \multicolumn{2}{|c|}{ Nonsevere } & \multicolumn{4}{|c|}{ Severe } & \multirow[b]{2}{*}{$\begin{array}{c}\text { Total } \\
\text { insurance } \\
\text { cost }(\$)\end{array}$} \\
\hline & & & & $\begin{array}{l}\text { Claims } \\
\text { (n) }\end{array}$ & $\begin{array}{l}\text { Medical } \\
\text { fees } \\
\text { (\$/claim) }\end{array}$ & $\underset{(\mathrm{n})}{\text { Claims }}$ & $\begin{array}{l}\text { Medical } \\
\text { fees } \\
(\$ / \text { claim })\end{array}$ & $\begin{array}{l}\text { Compensation } \\
\text { (\$/claim) }\end{array}$ & $\begin{array}{c}\text { Time } \\
\text { off work } \\
\text { (d/claim) }\end{array}$ & \\
\hline 2013/14 & 8,774 & 1,052 & 12.0 & 906 & 276 & 146 & 2,888 & 11,152 & 118 & $2,300,085$ \\
\hline $2014 / 15$ & 9,091 & 1,122 & 12.3 & 969 & 253 & 153 & 2,862 & 9,739 & 103 & $2,172,730$ \\
\hline $2015 / 16$ & 8,320 & 970 & 11.7 & 823 & 207 & 147 & 2,575 & 11,417 & 117 & $2,227,130$ \\
\hline Average & 8,354 & 987 & 11.8 & 839 & 252 & 148 & 2,419 & 9,334 & 97 & $1,946,025$ \\
\hline
\end{tabular}

${ }^{1}$ Accident Compensation Corporation, Wellington, New Zealand. Currency is New Zealand dollars (1 NZ\$ = US\$0.60 on May 19, 2020).

(14\%), farm managers (11\%), relief milkers (10\%), contract milkers or sharemilkers $(6 \%)$, and herd managers $(6 \%)$; the remaining group held a mixture of roles $(9 \%)$.

\section{National Accident Compensation Data}

An average of 8,354 ACC claims relating to the dairy industry were filed per year over the 5 yr from July 1, 2013, to June 30, 2018 (Table 2). Of these, 11.8\% (or 987 claims per year) were identified as relating to milking using the key word filter. Most of the claims related to milking were nonsevere (839 claims per year, or $85 \%$; i.e., required medical attention only and did not require time off work, which cost an average of NZ $\$ 252$ per claim). An average of 148 claims per year (15\%) required medical attention and compensation for time off work; these were classified as severe injuries. The average medical fee for these injuries was NZ $\$ 2,419$ per claim, and the average compensation was NZ $\$ 9,334$ / claim, for a total cost of NZ $\$ 11,753$ per claim. The total cost of milking injuries, medical fees, and compensation averaged NZ $\$ 1,946,025$ per year; the amount claimed was lower in 2016/17 and 2017/18 compared with the preceding $3 \mathrm{yr}$.

Examining the accident claims related to milking by injured body part, the greatest cost (medical fees and compensation) was for arm-elbow (NZ\$421,174/yr) and hand-wrist injuries (NZ\$321,527/yr). Considering the number of claims, the average costs were NZ $\$ 2,452$ and NZ\$2,264 per claim, respectively. On a claim basis, the most expensive claims were for leg injuries: upper leg injuries cost NZ $\$ 3,250$ per claim, and lower leg injuries cost NZ $\$ 2,880$ per claim. Using the key words "cupping" or "cluster" in the accident description field, the average cost per claim was NZ $\$ 2,732$. In terms of injury diagnosis group, soft-tissue injuries were the most expensive, at $\mathrm{NZ} \$ 1,170,317 / \mathrm{yr}$ (NZ $\$ 1,855$ per claim), followed by fractures and dislocations at NZ\$391,672/ yr (NZ\$4,285 per claim). On a claim basis, hernia (e.g., from lifting detergent drums) was the most expensive, at NZ $\$ 13,262$ per claim, followed by concussion or brain injury, at $\mathrm{NZ} \$ 8,828$ per claim.

\section{Combined Data Comparison}

Most injuries occurred in those aged 20 to $29 \mathrm{yr}$ (Table 3 ). We found no significant difference between the accident claim data and the on-farm survey data in terms of the age profile of injured people $(P=0.373)$, but we did find a significant difference $(P<0.001)$ between both data sets and information on the dairy workforce (determined from government census data). Workers aged 20 to 29 yr were overrepresented in both the accident claims and survey data sets, supported by a significant interaction between age group and source of data $(P<0.001)$.

Most injuries occurred in male milkers (Table 3). We found no significant difference between the accident claim data and the survey data in terms of the sex of injured people $(P=0.851)$, but we did find a significant difference $(P<0.001)$ between both data sets and information on the dairy workforce. Female milkers were overrepresented in both accident claims and the

Table 3. Comparison of sex and age results among data sources (onfarm survey, accident claims database, and dairy workforce)

\begin{tabular}{lccc}
\hline Sex & $\begin{array}{c}\text { On-farm } \\
\text { survey } \\
(\%)\end{array}$ & $\begin{array}{c}\text { Accident } \\
\text { claims } \\
\text { database }(\%)\end{array}$ & $\begin{array}{c}\text { Dairy } \\
\text { workforce } \\
(\%)^{1}\end{array}$ \\
\hline Female & 35 & 34 & 31 \\
Male & 65 & 66 & 69 \\
Age (yr) & 3 & 6 & 7 \\
15-19 & 25 & 29 & 21 \\
$20-29$ & 31 & 23 & 22 \\
$30-39$ & 20 & 22 & 22 \\
$40-49$ & 18 & 14 & 17 \\
$50-59$ & 3 & 5 & 11 \\
$60+$ & & 5 & \\
\hline
\end{tabular}

${ }^{1}$ Census data (Statistics New Zealand, 2013). 
Table 4. Comparison between on-farm survey data and accident claims database data by month and body part injured ${ }^{1}$

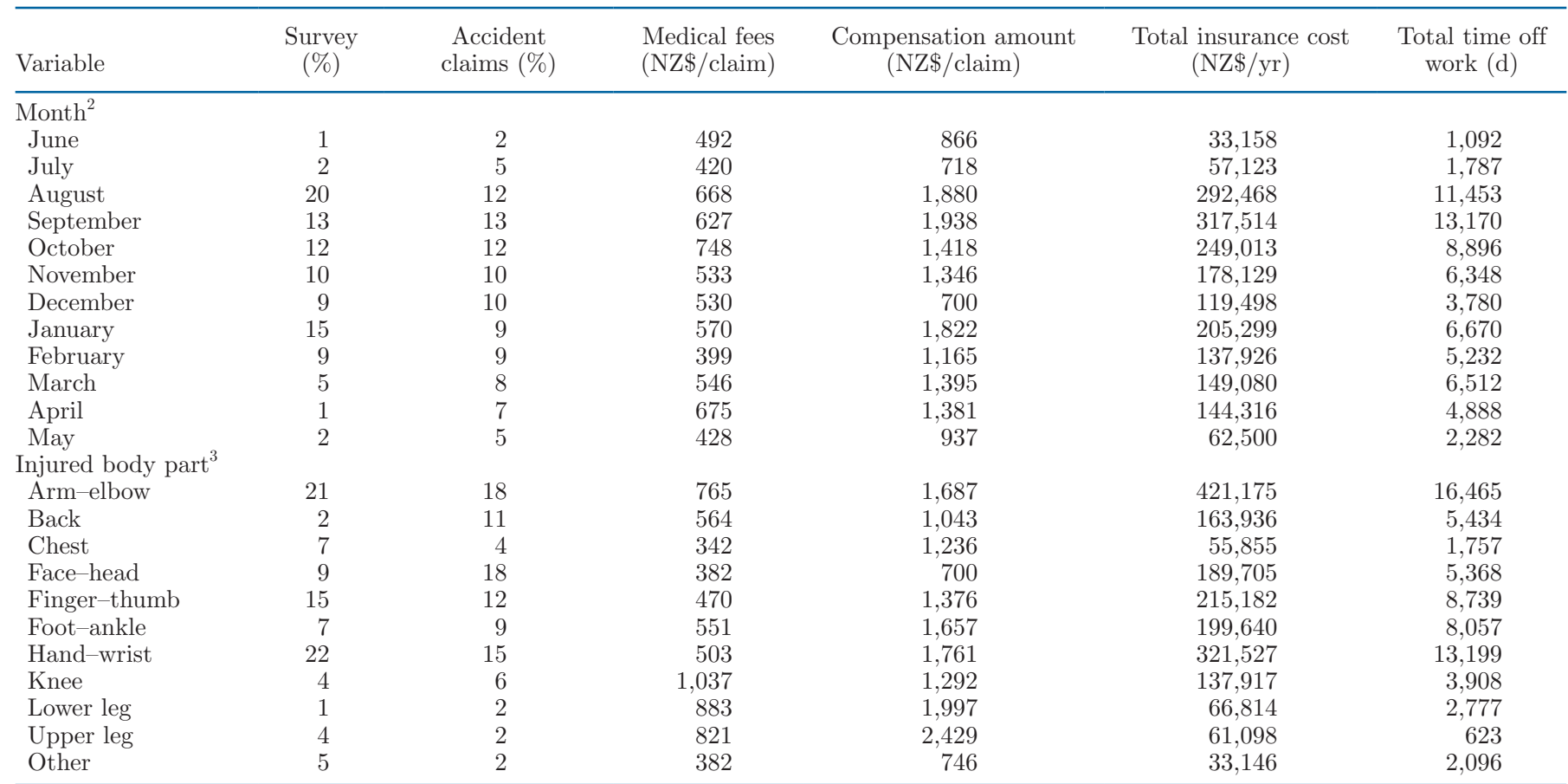

${ }^{1}$ Claim costs were an average per claim, noting that not all claims had compensation costs. Total cost was the average combined cost of medical fees and compensation per year. Costs are in New Zealand dollars (1 NZ\$ = US\$0.60 on May 19, 2020).

${ }^{2}$ Total surveys $=91$; total claims $=4,935$.

${ }^{3}$ Total surveys $=94 ;$ total claims $=4,759$.

survey data sets, supported by a significant interaction between sex and source of data $(P<0.001)$.

In the survey, over half of injuries $(52 \%)$ were soft-tissue injuries, bruises, or contusions. Similarly, soft-tissue injuries were the most common $(64 \%)$ in the accident claims data, followed by lacerations or punctures $(10 \%$ survey and $13 \%$ accident claims data) and fractures or dislocations ( $17 \%$ survey and $9 \%$ accident claims data). The arm, hand, wrist, and fingers were the body parts injured most commonly, with a combined total of $59 \%$ in the survey and $45 \%$ in the accident claims data (Table 4). However, face, head, and back injuries appeared more frequently in the accident claims data.

Similar seasonal trends were identified in the survey and accident claims data; most injuries occurred in August, and the fewest in May and June (Table 4). However, we found an increase in the number of injuries reported in the survey in January.

\section{Description of Farm and Milking Facilities in the Survey}

The farms included in the survey had a mean herd size of 449 cows and a parlor size of 36 clusters, and had 3 people working on the farm (Table 5). Mean milking time was $5.4 \mathrm{~h} / \mathrm{d}$, with more hours in rotary parlors (due to larger herds). Herringbone parlors were older than rotary parlors (Figure 1a). The mean cluster weight was $2.8 \mathrm{~kg}$, with little difference between parlor type, and the mean pit depth or platform height was $830 \mathrm{~mm}$; rotary parlors had greater working heights. Working heights have increased in newer parlors (Figure $1 \mathrm{~b}$ ). The mean height of the kick rail above where the milker stands was 1,462 $\mathrm{mm}$ and was $46 \mathrm{~mm}$ higher in rotary compared with herringbone parlors.

A steel bar or raised edge (a nib or lip) between cows' feet and the milker was present in $78 \%$ of herringbone and $9 \%$ of rotary parlors. Facilities to restrain animals for treatment (e.g., a "crush") were present in $33 \%$ of herringbone and $57 \%$ of rotary parlors; the remainder had a head-bail only. An electric wire connected to the collecting yard backing gate (to stop animals from preventing movement of the gate) was present in $38 \%$ of herringbone and $53 \%$ of rotary parlors. Automatic cluster removers were present for all clusters in $16 \%$ of herringbone parlors (and for some clusters on another $2 \%$ and $78 \%$ of rotary parlors. Automatic drafting was installed in $9 \%$ of herringbone and $50 \%$ of rotary parlors. Two-thirds of rotary parlors had "leg spreaders" mounted on the platform to encourage the cows 
Table 5. Descriptive statistics for farm characteristics by parlor type ${ }^{1}$

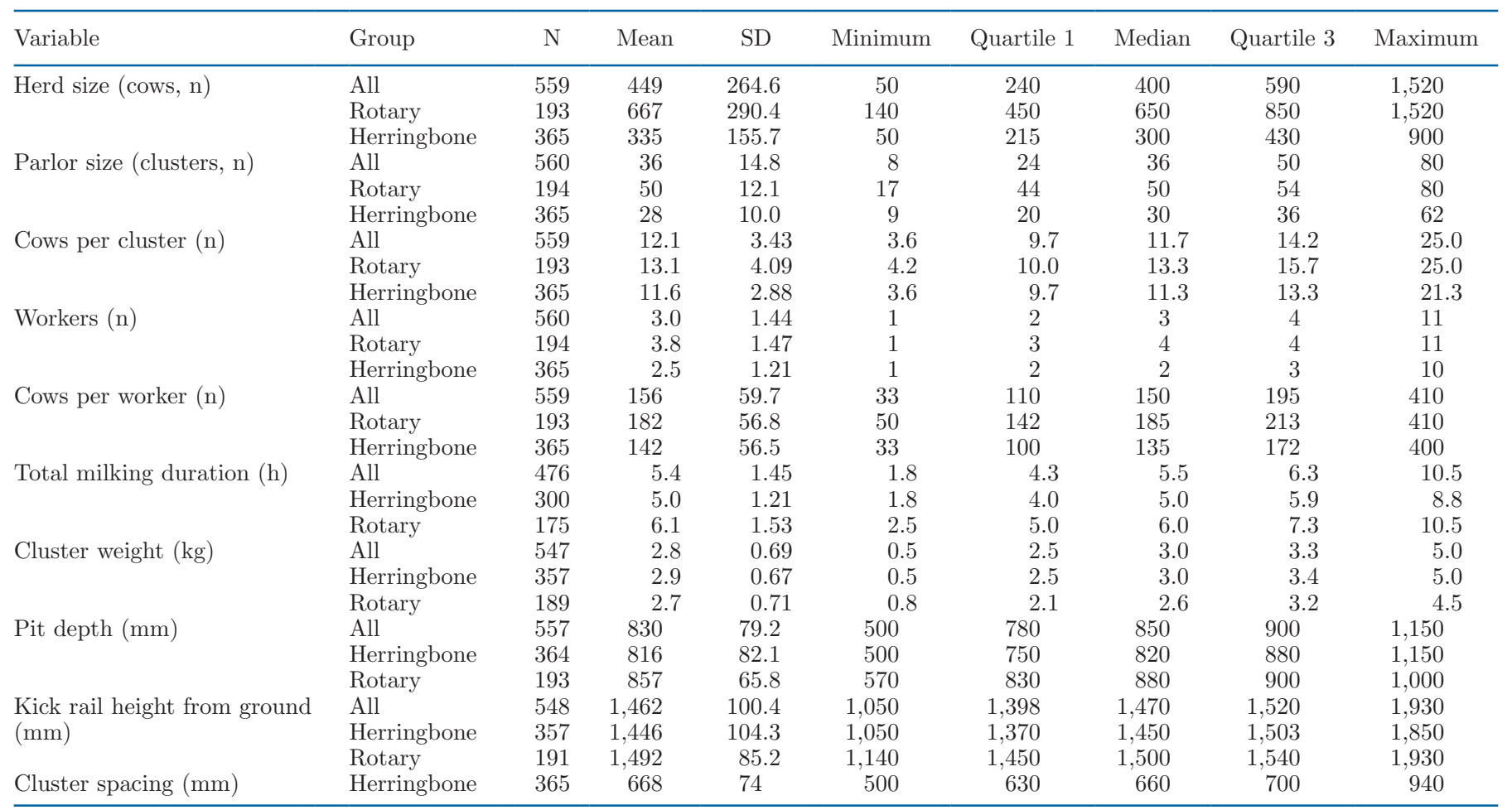

${ }^{1}$ Source: on-farm survey.

to stand with their legs apart to assist with cluster attachment; these devices are not used in herringbone parlors without stanchion bailing.

A number of questions were asked about factors that affected the milking routine in a herringbone parlor. In terms of the gate that controls cows' exit from parlor (not a rapid-exit gate), traditional swing gates that pivoted horizontally to open were present in $30 \%$ of parlors. Other gate types were pendulums that pivoted vertically up to open (39\% of parlors) and scissor-type gates that operated like pendulum gates but half pivoted vertically up and the other half pivoted vertically down to reduce weight for the operator $(28 \%$ of parlors); other types were present in $3 \%$ of parlors. Post-milking teat spraying was done using a bottle in $27 \%$ of herringbone parlors, using a spray gun on a long hose in $15 \%$, multiple spray guns (e.g., every $4-5$ cows) in $49 \%$, and an automated sprayer on the exit lane in $8 \%$ (other methods, $1 \%$ ). The gate in the collecting yard could be controlled from anywhere in the pit in $12 \%$ of herringbone parlors, at the cow entry end of the pit in $57 \%$, at the middle of the pit in $15 \%$, and in other locations in $16 \%$. Other features relating to milker comfort and health and safety were a "toe-in," which allows milkers to stand closer to the bail area so they do not have to reach when attaching clusters (present in $72 \%$ of herringbones), and a "step-up" rail mounted on the side of the pit to assist milkers in climbing up to the bail area for visual cow identification ( $16 \%$ of herringbone parlors). The most common type of rump rail, which can affect the position of the cow, was "straight" (61\%); the remaining were "zigzag" $(38 \%)$ or other $(1 \%)$.

\section{Description of Farm Management}

In spring, $1 \%$ of respondents said it was normal to work less than $40 \mathrm{~h} / \mathrm{wk}, 14 \%$ said 40 to $49 \mathrm{~h} / \mathrm{wk}, 43 \%$ said 50 to $59 \mathrm{~h} /$ wk, $23 \%$ said 60 to $69 \mathrm{~h} /$ wk, and $19 \%$ said $70 \mathrm{~h} /$ wk or more. The most common staff rosters used in spring were $12 \mathrm{~d}$ on $2 \mathrm{~d}$ off (25\%), no time off (24\%), and $11 \mathrm{~d}$ on $3 \mathrm{~d}$ off (11\%). Rosters such as $5 \mathrm{~d}$ on $2 \mathrm{~d}$ off and $6 \mathrm{~d}$ on and 1 or $2 \mathrm{~d}$ off were less common $(4,5$, and $7 \%$ respectively). Remaining rosters varied considerably, but the most common number of days on was 7 to 9 , with varying numbers of days off, used on $18 \%$ of farms. Pre-milking routines are not commonly practiced on farms in New Zealand; however, foremilk stripping is used to check for mastitis. Foremilk stripping of the herd was practiced more than weekly on $15 \%$ of farms, weekly on $17 \%$, fortnightly on $11 \%$, monthly on $32 \%$, and never on $25 \%$ of farms. New staff were trained in stockmanship and milking skills on $93 \%$ of farms. 
a)

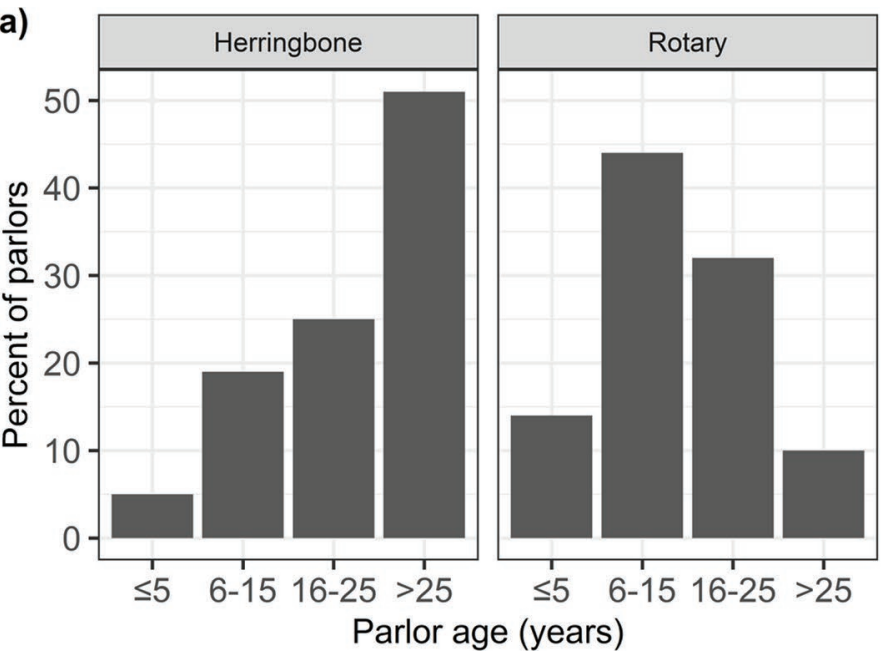

b)

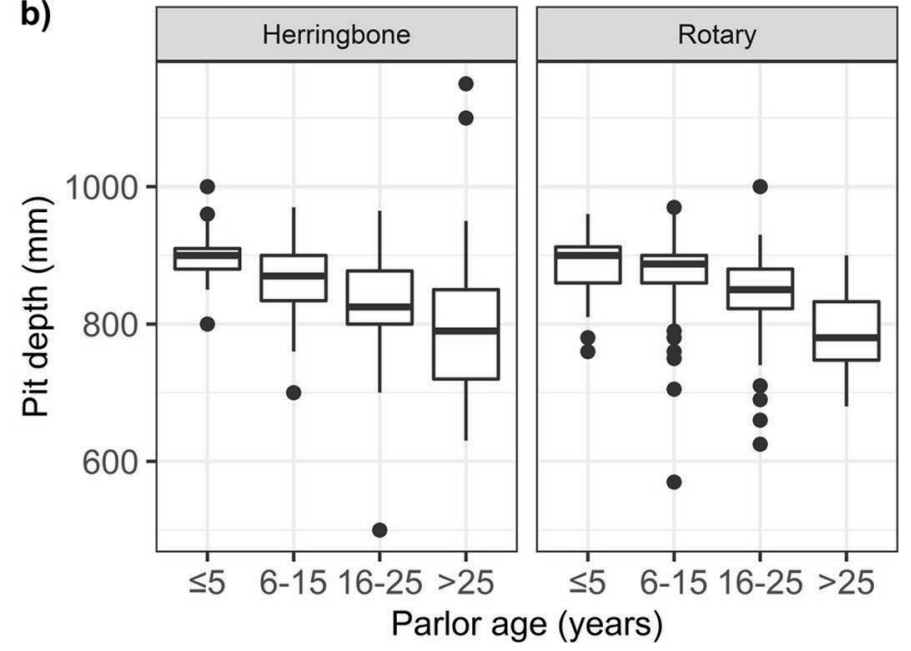

Figure 1. (a) Distribution of herringbone and rotary parlor ages, and (b) boxplot of pit depth (mm) by parlor age. The boxplots show the median (line within box), 25th and 75th percentiles (box), the largest or smallest data within or equal to $\pm 1.5 \times$ the interquartile range (whiskers), and outliers (dots). Source: on-farm survey.

\section{Links Between Injuries and Facilities and Management}

Farms that experienced an injury had more cows per cluster, more staff, and longer milking times than those that did not (Table 6). For herd size, parlor size, and cluster weight, the effect of injury was dependent on parlor type. For both types, farms that had injuries had greater herd sizes and parlor sizes; however, this finding was significant $(P<0.05)$ only for rotary parlors. For cluster weight, if the farm had a rotary parlor we found no difference between farms with or without injuries; however, clusters were lighter on farms with herringbone parlors that had injuries $(P<0.05$; Table 6$)$. Dividing cluster weight into 3 categories - below the lower quartile $(<2.5 \mathrm{~kg})$, above the upper quartile $(\geq 3.3 \mathrm{~kg})$, and between quartiles - we found no significant effect on the number of injuries $(P=0.08)$.

We found an effect of roster $(P<0.01)$, but those who did not have a rostered day off were not at the greatest risk of injury. We found no effect of the number hours worked per week $(P=0.485)$, use of training in stockmanship and milking skills $(P=0.802)$, breed $(P=0.407)$, or the regularity with which the farm used foremilk stripping $(P=0.189)$ on the prevalence of injuries.

When considering milker height and sex, females and shorter workers (females $\leq 1.65 \mathrm{~m}$ or males $\leq 1.75 \mathrm{~m}$ ) were at greater risk of injury $(P<0.05$ for sex and $P=0.058$ for height $)$. Although short females $(\leq 1.65$ $\mathrm{m})$ were at the greatest risk of injury, the interaction between sex and height was not significant $(P=0.145)$. Examining the height of the platform (rotary) or the depth of the pit (herringbone) for injured short females revealed a median of $880 \mathrm{~mm}$ (30 $\mathrm{mm}$ more than the median of $850 \mathrm{~mm}$ for all parlors), but this result was not statistically significant because of low sample numbers. We calculated a height coefficient (height of the platform or depth of the pit + an assumed $550 \mathrm{~mm}$ udder height $\div$ worker height) for injured males and

Table 6. Comparison of farm characteristics that did or did not have an injury by parlor type ${ }^{1}$

\begin{tabular}{|c|c|c|c|c|c|c|c|c|}
\hline Variable & \multicolumn{2}{|c|}{ Herringbone } & \multicolumn{2}{|c|}{ Rotary } & $\mathrm{SED}^{2}$ & \multicolumn{3}{|c|}{$P$-value } \\
\hline Parlor size (clusters, n) & 30 & 28 & 56 & 48 & 1.7 & $<0.001$ & $<0.001$ & 0.014 \\
\hline Cows per cluster (n) & 12.5 & 11.4 & 13.9 & 12.9 & 0.53 & $<0.001$ & 0.010 & 0.871 \\
\hline Workers (n) & 2.8 & 2.5 & 4.4 & 3.6 & 0.21 & $<0.001$ & 0.001 & 0.113 \\
\hline Cows per worker $(\mathrm{n})$ & 153 & 140 & 182 & 181 & 9.0 & $<0.001$ & 0.320 & 0.345 \\
\hline
\end{tabular}

${ }^{1}$ Source: on-farm survey.

${ }^{2} \mathrm{SED}=$ standard error of the difference. 
females; median values were 0.79 and 0.88 , respectively (Figure 2).

We found no effect on injuries of head gate type $(P$ $=0.170)$, the location of the head gate control $(P=$ $0.171)$, the teat spraying method $(P=0.267)$, the type of rump rail $(P=0.674)$, the presence of a "toe-in" $(P$ $=0.526)$, the presence of a "step-up" rail $(P=0.089)$, the distance between clusters in herringbone parlors $(P$ $=0.481)$, or the presence of leg spreaders in rotary parlors $(P=0.837)$. We found an effect $(P<0.001)$ of the location of the backing gate control on the number of injuries: more events occurred in dairies where the backing gate control was at the cow exit end of the pit.

\section{DISCUSSION}

Overall, the rate of injuries related to milking on the farms surveyed was $17.7 \%$, and $9.5 \%$ of farms had an accident insurance claim. In 2018/19, New Zealand had 11,372 dairy herds (DairyNZ, 2019), implying that about 1,076 accident claims could be expected per year, assuming no multiple claims for milking injuries on a single farm. This compared favorably with the average of 987 milking claims per year in the accident claims database (Table 2), given that not all milking injuries were likely to be identified through the key word search. The number of milking injuries as a percentage of injury claims (12\%; Table 2) was less than the $21 \%$ identified by Douphrate et al. (2009) in Colorado re-

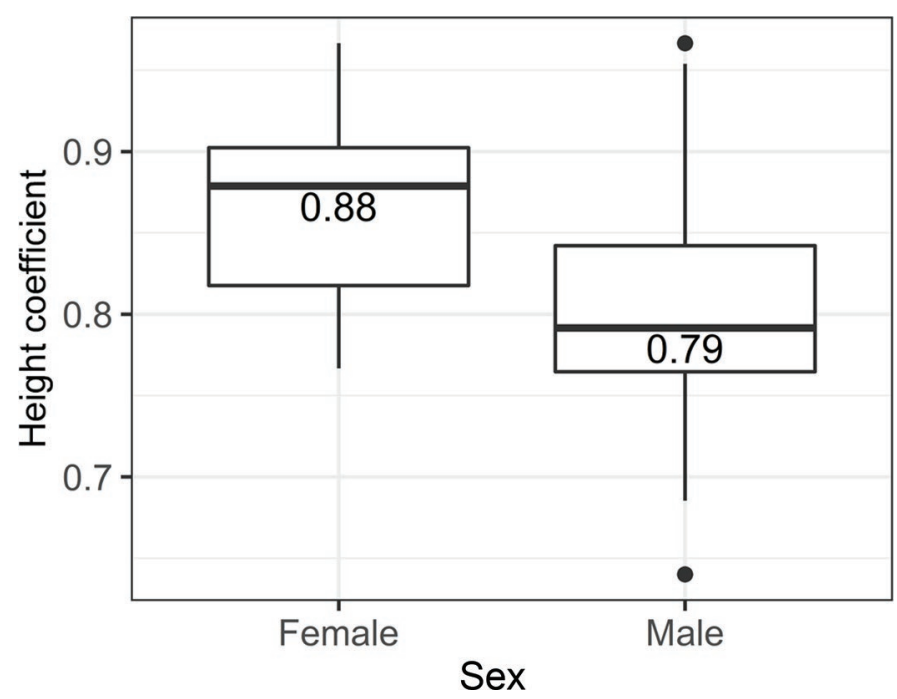

Figure 2. Boxplot of height coefficient for male and female injured workers. Height coefficient defined as the height of the platform or depth of the pit + an assumed $550 \mathrm{~mm}$ udder height $\div$ worker height (Cockburn et al., 2015). Label = median. The boxplots show the median (line within box), 25th and 75th percentiles (box), the largest or smallest data within or equal to $\pm 1.5 \times$ the interquartile range (whiskers), and outliers (dots). Source: on-farm survey. lated to milking or herding cows to the parlor. This difference may have been related to limitations of the key word search in the injuries database or the number of hours the parlor operates; parlors in the United States typically operate for a longer number of hours per day, with more workers than reported in the present survey (Wagner et al., 2001).

We identified a clear seasonal effect in both the survey and accident claims data, with a peak in August and a lull in June. This pattern matched the seasonal work type and demand in block calving systems that predominate in New Zealand, with cows typically calving in August (spring) and not lactating in June. This seasonal trend was similar to that reported by Watts and Meisel (2011) in New Zealand, although their study included all injuries relating to animals, not only from dairy farms or milking. To illustrate the work demands in spring, $23 \%$ of respondents in the on-farm survey reported working 60 to $69 \mathrm{~h} /$ wk and $19 \%$ working $70+$ h/wk; further, $24 \%$ said they had no time off in spring, and $25 \%$ operated a roster of $12 \mathrm{~d}$ on $2 \mathrm{~d}$ off. Previous studies have identified a relationship between hours worked and number of injuries (Hwang et al., 2001). In the survey, we identified an increase in injuries in January. One explanation was that it may have been related to the summer holiday period and changes in farm routines (to save time), work rosters, or the use of relief staff. Knowledge of this seasonal pattern could be applied in the context of injury mitigation, with interventions for the busy spring period a priority. However, we found no association between hours worked per week and the number of milking injuries; we found an effect of work roster, but no clear pattern (e.g., rosters with many consecutive work days were not associated with greater risk of injury). This could have been due to considerable variations in roster types or because of larger factors of influence.

The rates of injuries of males $(65 \%)$ and females $(35 \%)$ in the on-farm survey were similar to the rates of 66 and $34 \%$ in the accident claims database, respectively. This finding was significantly different from the $69 \%$ males and $31 \%$ females estimated to work in the dairy industry (Statistics New Zealand, 2013). For context, Watts and Meisel (2011) reported in Southland (New Zealand) a split related to sex of 68 and $32 \%$ relating to all injuries caused by all cattle. International studies have reported a greater incidence of injury for female workers milking (Stål et al., 1996). This may be a result of anthropomorphic differences between males and females. The greater risk identified for short females in the current study may relate to working heights (Figure 2). Using numbers from Jakob and Liebers (2017), and assuming that the udder base was $550 \mathrm{~mm}$ above the cows' feet and the distance from the head to the 
shoulder was $300 \mathrm{~mm}$, the ideal pit height using the formula of Jakob et al. (2012) would be $800 \mathrm{~mm}$ for a person $1.65 \mathrm{~m}$ tall. An alternative method using the same udder height and a parlor-specific constant factor of 0.75 for rotary and $50^{\circ}$ herringbone parlors estimates an even lower ideal height of $687.5 \mathrm{~mm}$ (Cockburn et al., 2015), although this approach has been questioned by Jakob and Liebers (2017) because it might result in stooping. In comparison, the median working height across all parlors in the current study was $850 \mathrm{~mm}$, lower for herringbone parlors than for rotaries (Table $5)$. Further, the median height of the parlors in which the injured females $\leq 1.65 \mathrm{~m}$ were working was 880 $\mathrm{mm}$, indicating that these milkers would have been reaching to attach clusters and that this may have been a factor contributing to their injuries. The working height in rotary dairies is influenced by the milking plant manufacturer and by the individual shed builder in herringbone parlors (of which there are considerably more than milking plant manufacturers), which may explain the greater variation for herringbone parlors. Rotary parlors offer greater flexibility in terms of customizing workstations between workers with different anthropometrics because the milker typically stands in a consistent position compared with herringbone parlors (e.g., matting to adjust floor height), a concept supported by Douphrate et al. (2017a). Adjustable floors in herringbone parlors are an option (Cockburn et al., 2017), but in addition to the barrier of cost, it would be challenging to determine the optimal height if 2 workers of different heights were required in the parlor simultaneously because of the number of clusters; focusing on sturdy adjustable footwear could be a more practical and affordable option. The trend for increasing working height in newer dairies (Figure 1b) and its implications for worker safety warrant further investigation.

We found more injuries on farms with more staff and longer milking durations. The age and experience levels of staff may be contributing factors, although $93 \%$ of farmers indicated that they trained new staff in stockmanship and milking skills. The dairy industry in New Zealand has grown significantly in the last 2 decades, and with it the average herd size (DairyNZ, 2019). Labor for this expansion has been sourced from immigration or from people from non-farming backgrounds (Trafford and Tipples, 2011). These workers would typically enter the industry as farm assistants (Collins and Bayliss, 2020), the group with the highest prevalence of injuries. Similarly, those in aged 20 to 29 yr were overrepresented in survey and accident claims data relative to their proportion in the workforce. These results suggest that current training in milking routines or stockmanship may not be of sufficient qual- ity. Of these, training in milking routines may provide a greater return because once a routine is established for a parlor, new staff can be taught by existing staff, meaning a smaller number of people need to be reached than for stockmanship; routines also benefit milking efficiency.

A theme emerged in the data: the milking activity during which where injuries occurred most often was when actively milking cows (56\%), and the most common injury-related activity was attaching or removing clusters from cows (48\%). This finding aligned with the majority of injuries occurring in the extremities near the cluster - the hand, wrist, finger and arm and involving a bruise or soft-tissue injury, or a fracture, break, or dislocation. These injuries were consistent with being kicked by a cow, which was the most common reason for injury identified by Douphrate et al. (2009), Murphy et al. (2010), and Watts and Meisel (2011). Previous research has explored a support arm (Stål et al., 2003) and a quarter milking device (Jakob and Liebers, 2011; Jakob, 2019) to assist with cluster attachment; both reduced muscle load. However, these devices are unlikely to see widespread adoption in lowcost, pasture-based systems - in the case of the support arm, because of large variability in bovimetrics, and for both devices, because of difficulty retrofitting to swing-over herringbone parlors and additional mechanical complexity. Further, these devices have an unknown effect on acute cluster attachment injuries. A simpler, lower-cost option that would be easier to adopt could relate to the milking cluster itself. Interestingly, in herringbone parlors, farms that had injuries had lighter clusters. In some respects this is counterintuitive; research has shown that lighter clusters resulted in lower muscle load (Jakob et al., 2012). However, the design of the cluster also affects the ease with which it can be attached, as demonstrated by Douphrate et al. (2017b): the cluster most preferred by study participants was not the lightest. Given that arm, hand, wrist, and finger injuries made up the greatest insurance cost (Table 4), the effect of cluster design and its interaction with anthropometrics (e.g., hand size) and cluster attachment method on milker comfort and attachment time warrants further investigation as a way of reducing milker fatigue (potentially affecting reaction times to injury-causing events) and the time spent within kicking distance (hands under the udder attaching teat cups). Furthermore, the development of a simple handarm guard to minimize impact in the event of a kick may assist in reducing milking injuries.

In an attempt to maximize the number of respondents, the survey was included in existing annual parlor audits, which meant that many $(>30)$ surveyors were collecting data. Although we used a training resource, 
including marked photos, to train surveyors to ensure consistent data capture, it is possible that question interpretations varied. Further, the number of injuries reported $(\mathrm{n}=99)$ limited the ability to link injuries to facility design and management (objective 3 ). This number was smaller when identifying factors for specific injury-related activities (e.g., $\mathrm{n}=47$ for attaching clusters). Nevertheless, the identification of common causes of injuries relating to milking and quantification of the variation in parlor design has provided useful direction for investigating strategies to mitigate milking injuries.

\section{CONCLUSIONS}

Overall, $18 \%$ of farms had had a milking injury, although only half of these led to an insurance claim. About half of injuries occurred while workers were attaching clusters, typically soft-tissue and fracture injuries to hands, wrists, fingers, and arms. Injuries to these body parts represented the greatest cost and identified safe cluster attachment as an area of focus for reducing milking injuries. Potential low-cost solutions included improved cluster design and a hand--arm guard. Relative to their proportion of the workforce, more injuries occurred in workers aged 20 to $29 \mathrm{yr}$, indicating that training quality could be improved. Establishing ergonomic milking routines could provide a greater return than stockmanship training. We identified a clear seasonal trend coinciding with busy periods in a seasonal block calving system, suggesting that options to reduce fatigue in spring may be beneficial; however, the number of hours worked or number or consecutive days worked were not associated with the number of milking injuries. Female workers were at greater risk of injury than males; this may have been related to working height in the parlor and warrants further investigation.

\section{ACKNOWLEDGMENTS}

This study was funded by WorkSafe New Zealand (Wellington, New Zealand; contract 506090). We thank J. Wheeler and R. Hall (QCONZ) for their input into the survey design and piloting the survey; Fonterra Cooperative Group Ltd. for allowing the dairy auditors of QCONZ and AsureQuality to conduct surveys at annual parlor audits; and the auditors of these companies for collecting the data. We also thank C. Leach (QCONZ) and A. Leslie (DairyNZ) for conducting surveys in the Southland and the West Coast regions, respectively, and C. Eastwood and B. Dela Rue (DairyNZ) for their support. The authors have not stated any conflicts of interest.

\section{REFERENCES}

Beggs, D. S., A. D. Fisher, E. C. Jongman, and P. H. Hemsworth. 2015. A survey of Australian dairy farmers to investigate animal welfare risks associated with increasing scale of production. J. Dairy Sci. 98:5330-5338. https://doi.org/10.3168/jds.2014-9239.

Cockburn, M., P. Savary, M. Kauke, M. Schick, U. Hoehne-Hückstädt, I. Hermanns, and R. Ellegast. 2015. Improving ergonomics in milking parlors: Empirical findings for optimal working heights in five milking parlor types. J. Dairy Sci. 98:966-974. https://doi.org/10 .3168/jds.2014-8535.

Cockburn, M., M. Schick, N. A. Maffiuletti, L. Gygax, P. Savary, and C. Umstätter. 2017. Lower working heights decrease contraction intensity of shoulder muscles in a herringbone $30^{\circ}$ milking parlor. J. Dairy Sci. 100:4914-4925. https://doi.org/10.3168/jds.2016 -11629 .

Collins, F. L., and T. Bayliss. 2020. The good migrant: Everyday nationalism and temporary migration management on New Zealand dairy farms. Polit. Geogr. 80:102193. https://doi.org/10.1016/j .polgeo.2020.102193.

Dairy NZ. 2018. Dairy tomorrow: The future of New Zealand dairying. Accessed Aug. 27, 2018. http://www.dairytomorrow.co.nz/.

Dairy NZ. 2019. New Zealand dairy statistics 2018-19. Accessed Dec. 12, 2019. https://www.dairynz.co.nz/media/5792393/nz-dairy -statistics-2018-19-web.pdf.

Deming, J., D. Gleeson, T. O'Dwyer, J. Kinsella, and B. O'Brien. 2018. Measuring labor input on pasture-based dairy farms using a smartphone. J. Dairy Sci. 101:9527-9543. https://doi.org/10 .3168/jds.2017-14288.

Douphrate, D. I., N. B. Fethke, M. W. Nonnenmann, A. Rodriguez, R. Hagevoort, and D. Gimeno Ruiz de Porras. 2017a. Full-shift and task-specific upper extremity muscle activity among US large-herd dairy parlour workers. Ergonomics 60:1042-1054. https://doi.org/ 10.1080/00140139.2016.1262464.

Douphrate, D. I., D. Gimeno Ruiz de Porras, M. W. Nonnenmann, R. Hagevoort, S. J. Reynolds, A. Rodriguez, and N. B. Fethke. 2017b. Effects of milking unit design on upper extremity muscle activity during attachment among U.S. large-herd parlor workers. Appl. Ergon. 58:482-490. https://doi.org/10.1016/j.apergo.2016.08.008.

Douphrate, D. I., M. W. Nonnenmann, R. Hagevoort, and D. Gimeno Ruiz de Porras. 2016. Work-related musculoskeletal symptoms and job factors among large-herd dairy milkers. J. Agromedicine 21:224-233. https://doi.org/10.1080/1059924X.2016.1179612.

Douphrate, D. I., J. C. Rosecrance, L. Stallones, S. J. Reynolds, and D. P. Gilkey. 2009. Livestock-handling injuries in agriculture: An analysis of Colorado workers' compensation data. Am. J. Ind. Med. 52:391-407. https://doi.org/10.1002/ajim.20686.

Douphrate, D. I., L. Stallones, C. Lunner Kolstrup, M. W. Nonnenmann, S. Pinzke, G. R. Hagevoort, P. Lundqvist, M. Jakob, H. Xiang, L. Xue, P. Jarvie, S. A. McCurdy, S. Reed, and T. Lower. 2013. Work-related injuries and fatalities on dairy farm operations-A global perspective. J. Agromedicine 18:256-264. https:// doi.org/10.1080/1059924X.2013.796904.

Edwards, J. P., B. Kuhn-Sherlock, B. T. Dela Rue, and C. R. Eastwood. 2020. Short communication: Technologies and milking practices that reduce hours of work and increase flexibility through milking efficiency in pasture-based dairy farm systems. J. Dairy Sci. 103:7172-7179. https://doi.org/10.3168/jds.2019-17941.

Hwang, S.-A., M. I. Gomez, A. D. Stark, T. L. St. John, J. J. May, and E. M. Hallman. 2001. Severe farm injuries among New York farmers. Am. J. Ind. Med. 40:32-41. https://doi.org/10.1002/ajim 1069 .

Jakob, M., and F. Liebers. 2011. Potential of a quarter individual milking system to reduce the workload in large-herd dairy operations. J. Agromedicine 16:280-291. https://doi.org/10.1080/ 1059924X.2011.605713.

Jakob, M., F. Liebers, and S. Behrendt. 2012. The effects of working height and manipulated weights on subjective strain, body posture and muscular activity of milking parlor operatives-Laboratory study. Appl. Ergon. 43:753-761. https://doi.org/10.1016/j.apergo .2011.11.009. 
Jakob, M. C. 2019. Evaluation of a physical ergonomic intervention for milking parlor operatives-A case study. J. Agromedicine 24:215223. https://doi.org/10.1080/1059924X.2019.1590270.

Jakob, M. C., and F. Liebers. 2017. Comparison of 2 recommendations for adjusting the working height in milking parlors. J. Dairy Sci. 100:6620-6630. https://doi.org/10.3168/jds.2016-12034.

Murphy, C. G., C. M. McGuire, N. O'Malley, and P. Harrington. 2010. Cow-related trauma: A 10-year review of injuries admitted to a single institution. Injury 41:548-550. https://doi.org/10.1016/j .injury.2009.08.006.

Stål, M., U. Moritz, B. Gustafsson, and B. Johnsson. 1996. Milking is a high-risk job for young females. Scand. J. Rehabil. Med. 28:95-104.

Stål, M., S. Pinzke, and G.-Å. Hansson. 2003. The effect on workload by using a support arm in parlour milking. Int. J. Ind. Ergon. 32:121-132. https://doi.org/10.1016/S0169-8141(03)00046-5.

Statistics New Zealand. 2013. Integrated Data Infrastructure. Statistics New Zealand, Wellington, New Zealand.

Teagasc. 2018. Sustainable dairying: Workplace action plan. Accessed Oct. 27, 2019. https://www.teagasc.ie/media/website/ publications/2018/People-in-Dairy-Action-Plan.pdf.
Trafford, S., and R. Tipples. 2011. Where will the milkers come from? A future employment conundrum for New Zealand's largest export industry. Employ. Relat. Rec. 11:43-61.

Wagner, A., R. W. Palmer, J. Bewley, and D. B. Jackson-Smith. 2001. Producer satisfaction, efficiency, and investment cost factors of different milking systems. J. Dairy Sci. 84:1890-1898. https://doi .org/10.3168/jds.S0022-0302(01)74630-9.

Watts, M., and E. M. Meisel. 2011. Cattle associated trauma-A one year prospective study of all injuries. Injury 42:1084-1087. https:/ /doi.org/10.1016/j.injury.2011.02.019.

\section{ORCIDS}

J. P. Edwards (1) https://orcid.org/0000-0003-4220-7408

B. Kuhn-Sherlock @ https://orcid.org/0000-0002-1890-0301 